\title{
Halophilic Bacterium - A Review of New Studies
}

\author{
Bassam Oudh Aljohny \\ Department of Biological Science, Faculty of Science, King Abdulaziz University, \\ P.O. Box 80203, Jeddah 21589, Kingdom of Saudi Arabia.
}

DOI: http://dx.doi.org/10.13005/bbra/1874

(Received: 15 September 2015; accepted: 16 November 2015)

\begin{abstract}
Halophilic bacteria are organisms which thrive in salt-rich environments, such as salt lakes, solar salterns and salt mines which contain large populations of these organisms. In biotechnology, such salt-tolerant bacteria are widely used for the production of valuable enzymes, and more than a thousand years ago humans began using salt to cure and thereby preserve perishable foods and other materials, such as hides; halophiles can be detrimental to the preservation of salt brine cured hides. The aim of this review is to provide an overview of the taxonomy of these organisms including novel isolates from rock salt, and also to discuss their current and future biotechnological and environmental uses.
\end{abstract}

Keywords: Hypersaline environments, Halophilic bacteria, Environmental and Industrial application.

Halophiles are microorganisms that can adapt to growth in moderate and high salt concentrations and in biotechnology are extensively used for a number of applications, including the production of valuable enzymes. Despite this, halophiles have remained a somewhat neglected group of bacteria. Halophiles cover all there domains, namely Archaea, Bacteria and Eucarya, and contain representatives of many different physiological types, adapted to a wide range of salt concentrations as high as salt saturation. Earlier reviews have discussed the possible applications of halophiles in biotechnological and environmental processes; DasSarma and Arora, 1997, ${ }^{1}$ for example have provided information on the limited current and potential practical uses of these organisms.

Halophiles have developed two different adaptive strategies to cope with the osmotic pressure induced by the high $\mathrm{NaCl}$ concentration

\footnotetext{
* To whom all correspondence should be addressed. Tel.: + 966555574781;

E-mail: boaljohny@kau.edu.sa
}

of the environments in which they live. Halobacteria species and some extremely halophilic bacteria, for example, accumulate inorganic ions in the cytoplasm $(\mathrm{K}+, \mathrm{Na}+, \mathrm{Cl})$ in order to balance the osmotic pressure of the medium. Additionally, they have developed specific proteins that are stable and active in the presence of salt. In contrast, moderate halophiles accumulate (within the cytoplasm) large amounts of specific organic osmolytes, which function as osmoprotectants, providing osmotic balance without interfering with the normal cellular metabolism.

Biotechnological applications of halophiles include the production of compatible solutes, biopolymers and carotenoids; they have also been evaluated for use in various environmental bioremediation processes. In addition to being intrinsically stable and active at high salt concentrations, halophilic enzymes can be used in food processing, environmental bioremediation and biosynthetic processes; as a result, discovering novel enzymes, showing optimal activities at various ranges of salt concentrations, temperatures and $\mathrm{pH}$ values is of considerable 
potential economic importance. Such enzymes from halophiles can also be used in industrial applications which do not involve high salt concentrations since such exoenzymes can usually tolerate high temperatures and are stable in the presence of organic solvents.

\section{Halophiles}

Halophiles are salt-loving organisms that inhabit hypersaline environments. The group includes mainly prokaryotic and eukaryotic microorganisms with the capacity to balance the osmotic pressure of the environment and resist the denaturing effects of high salt concentrations. Normally, organisms living in salt-rich environments lose water and die as the result of osmosis. In order to survive in salt-rich environments, the cytoplasm of halophiles must be isotonic with the environment ${ }^{2}$. In order to reach this state, they use two different methods. In the first (mainly used by bacteria, some archaea, yeasts, algae and fungi), organic compounds are stored in the cytoplasm; such compounds help the organism survive osmotic stress ${ }^{3}$. The most commonly used solutes used in this process are neutral amino acids and sugars ${ }^{4}$. An important disadvantage of this method is that it requires the organism to use considerable amounts of energy. The second, and less common adaptation to salt, involves the selective intake of potassium $\left(\mathrm{K}^{+}\right)$ions into the cytoplasm. In exchange, the organism pumps sodium $\left(\mathrm{Na}^{+}\right)$ions out with the help of the sodium-potassium pump ${ }^{5}$. Ions of sodium may also be used but less frequently so than potassium $^{6}$. This adaptation is only used by one order of bacteria and a single family of Archaea ${ }^{7}$. An advantage of this approach is that it uses much less energy than the previously mentioned adaption. The main disadvantage with this approach is that all of the machinery within the cell (enzymes, structural proteins, etc.) must be adapted to high levels of non-organic ions and high salt levels; such an approach turns out to be much more demanding than the use of compatible solutes. Most halophiles use only use one of these two approaches, although a few halophiles can use both.

\section{Taxonomy and phylogeny of halophiles}

The first halophilic fermentative bacterial species, Halanaerobium praevalens was isolated from the sediments of the Great Salt Lake (Utah) and characterized in $1983^{8}$ and placed firmly in the family Bacteroidaceae as a genus with uncertain affiliation ${ }^{8}$. The characterization of $H$. praevalens was followed by the isolation and characterization of Halobacteroides halobius in 1984 from the sediments of Dead Sea and similarities in 16S rRNA sequences between the two halophilic fermentative bacteria were observed leading to placement of the species in a new family, namely the Haloanaerobiaceae ${ }^{9,10}$. A third genus was added to the family Haloanaerobiaceae in 1987, when Clostridium lortetii, was isolated from the sediments of Dead Sea and originally characterized in 1983, was transferred to a new genus of the family and renamed as Sporohalobacter lortetii. 11,12 .

Between the years 1987 and 1995, five new halophilic fermentative genera, Halothermothrix, Halocella, Acetohalobium, Halanaerobacter, and Orenia, were characterized and placed in the family Haloanaerobiaceae $e^{12,13,141516}$. Eventually, in 1995, a new order (named as Haloanaerobiales) for the halophilic fermentative bacteria was proposed ${ }^{17}$. In addition, as the result of taxonomic studies and phylogenetic analyses of the halophilic fermentative bacterial genera, a novel family (named as Halobacteroidaceae) was proposed and the genera Halobacteroides, Acetohalobium, Halanaerobacter, Sporohalobacter, and Orenia were re-assigned to this novel family ${ }^{17}$.

The extremely halophilic archaea (also called haloarchaea or, traditionally, "halobacteria”) belong to the order Halobacteriales, which contains only a single family, the Halobacteriaceae ${ }^{18}$; since the publication of Bergey's Manual of Systematic Bacteriology (2001), which listed 14 recognized haloarchaeal genera, the number has increased to 19 genera i.e. according to the International Committee on Systematics of Prokaryotes (http://www.theicsp.org). The number of validated species currently stands at 57. One taxonomic criterion for the identification and recognition of haloarchaea is the sequence of the 16S rRNA genes; specific signature sequences and signature bases as detailed by Kamekura et al. (1982), ${ }^{19}$ who also recommend the determination of 23S rRNA gene sequences for more refinement.

The currently recognized genera and species of the family Halobacteriaceae are listed in 
Table 1; also shown are the data bank accession numbers for the 16S rRNA gene sequences. Historically, the composition of membrane polar lipids has long been used as one of the key chemotaxonomic criteria for the differentiation of haloarchaeal genera ${ }^{19,20}$.

All haloarchaea examined to date possess ether-linked phosphoglycerides; phosphatidyl glycerol and phosphatidyl glycerol phosphate methyl ester are always present; many strains contain phosphatidyl glycerol sulfate and one or more glycolipids or sulfated glycolipids ${ }^{18}$; most glycerol ether core lipids contain C20C20 (diphytanyl) isoprenoids, although some strains, notably haloalkaliphiles, possess also C20C25 (phytanyl-sesterterpanyl) or C25C25 (disesterterpanyl) isoprenoid chains. Halobacterial taxonomy, based on the polar lipid composition, has proved to be remarkably consistent with phylogenetic data deduced from 16S rRNA gene sequence comparisons ${ }^{18}$. Halobacteria (haloarchaea) are a monophyletic group, with the most distantly related species showing a 16S rRNA gene sequence similarity of $83.2 \%{ }^{18}$. The methanogens, another archaeal group, are their closest relatives, with less than 80\% 16S rRNA gene sequence similarity ${ }^{21}$. The complete list of required and recommended criteria for the determination and recognition of haloarchaeal species has been proposed ${ }^{22}$. Three genomes of haloarchaea have been sequenced, namely Halobacterium salinarum NRC- ${ }^{23}$, Haloarcula marismortui ${ }^{24}$ and Natronomonas pharaonis ${ }^{25}$.

Industrial Application of Halophilic Microorganisms

The production of solar salt

Traditional salt making by evaporation of seawater in shallow ponds in coastal areas takes place in the tropics and subtropics ${ }^{26}$. As the brine approaches saturation and salt starts to crystallize, the it become coloured red. Three types of halophilic microorganisms contribute to the colour: extremely halophilic Archaea (family Halobacteriaceae) containing 50-carbon carotenoids (bacterioruberin and derivatives) and sometimes also the retinal protein bacteriorhodopsin (see below), the $\beta$-carotenerich unicellular green flagellate alga Dunaliella salina and finally, the red halophilic bacterium Salinibacter rubber, which contains a unique C40- carotenoid acyl glycoside. In less saline ponds where the earlier evaporation stages take place, dense microbial mats develop on the bottom, these being composed of a range of different cyanobacteria as well as many other types of microorganisms.

The importance of these bacteria in the salt making process only started to be recognized in the 1970s when it was realized that microorganisms play a role in determining the quality and quantity of the salt harvested, realization which led to the development of biological management practices for the operation of solar salterns ${ }^{27,28}$. Microbial processes it seems influence the size and quality of the salt crystals formed in solar saltern crystallizer ponds. At some sites large solid halite crystals precipitate that are easy to process and yield a high-quality product, while elsewhere, crystals are soft, with a high content of entrapped mother liquor, making them difficult to harvest and to purify; where seawaters of nearly identical composition exist, biological processes may account for these differences by influencing evaporation and/or crystallization.

\section{Halophiles and Fermented foods}

Large amounts of salt are used in the preparation of certain types of traditionally fermented foods. Such salt-rich food products are especially popular in the Far-East. Examples include 'jeotgal', traditional Korean fermented seafood, the Japanese 'fugunoko nukazuke' prepared by fermentation of salted puffer fish ovaries in rice bran, and 'nam-pla', a Thai fish sauce. The latter product is made by adding two parts of fish and one part of marine salts. The mixture is covered with concentrated brine (25-30\% $\mathrm{NaCl}$ ) and allowed to ferment for around a year. Surprisingly relatively little is known about the microorganisms involved in the preparation of these foods and about the roles they play in the production process. In some cases, the salt concentration during the fermentation process is sufficiently high for the development of Archaea of the family Halobacteriaceae. The first halophilic archaeon obtained from Thai fish sauce (nam pla) was an isolate resembling Halobacterium salinarum ${ }^{29}$, and two new species, Halococcus thailandensis and Natrinema gari, were recently isolated ${ }^{30,31}$. Halalkalicoccus jeotgali is a novel isolate obtained from shrimp jeotgal ${ }^{32}$. 


\section{Halophiles and Biopolymers}

Biosurfactants and other biopolymers have been produced using non-fermentative halophilic bacteria, but not fermentative halophiles a result which may reflect the fact that fermentative halophilic strains have been relatively little studied. Biosurfactants are biopolymers which are able to decrease surface tension in liquids thereby increasing the motility of hydrophobic hydrocarbons. They have been used in the bioremediation of oil-contaminated hypersaline soil or water, and may also be useful for use in in situ microbialy-enhanced oil recovery. The is based on the fact that many petroleum reservoirs are hypersaline and exist at high temperature, making it likely that halothermophilic bacteria could find a practical us in this technology ${ }^{33}$.

\section{Halophiles and Enzyme Production}

Halophilic microorganisms produce stable enzymes, including many hydrolytic enzymes such as DNAses, lipases, amylases, gelatinises, and proteases. Such enzymes are able to function under high concentrations of salt which would normally lead to the precipitation or denaturation of most proteins, including enzymes. Most halophilic enzymes are inactivated and denatured at concentrations of $\mathrm{NaCl}$ below 1M. Enzymes produced by halophilic fermentative bacteria in contrast are salt tolerant and, actually, saltrequiring due to their need to maintain high intracellular ion concentrations maintained for balancing the osmotic pressure in hypersaline environments. Most interest in relation to halophilic enzymes has been devoted to isomerases and hydrolases, including amylases that catalyze the bioprocessing of starch and galactosidases which catalyze the bioprocessing of lactose. Salt-require ring enzymes have been cloned and produced as inactive forms in Escherichia coli and subsequently successfully activated with increase of salt concentration ${ }^{34}$.

\section{Halophiles and Alternative Energy}

Environmental issues, notably climate change are currently of common public concern and there is an urgent and constant need for alternative renewable energy sources, such as bioethanol, biobutanol, and biohydrogen. Currently, butanol production by halophilic fermentative bacteria has yet to be reported, but many halophilic fermentative species are known to produce ethanol, however, according to the best of our knowledge, halophilic ethanol production has not been studied in more detail.

Hydrogen is a renewable and clean source of energy and thus considered an important future potential energy carrier, particularly since it has a very high heat value and is readily combustible, with water being the sole end product, making it an environmental friendly potential future energy source. Biological hydrogen production in hypersaline environments would not only be sustainable but also carefully protected from contamination by non-hydrogen producing organisms; halophilic hydrogen utilizing methanogens for example, rarely contaminate bioprocesses $^{2,7}$. As a result, the sterilization costs needed before halophilic hydrogen production can begin are likely to be minimized, particularly where high volumes are employed. Hydrogen production using glycerol has been achieved using $H$. saccharolyticum $^{35}$. The highest hydrogen yields were achieved by using $2.5 \mathrm{~g} / \mathrm{l}$ glycerol and $150 \mathrm{~g} /$ 1 salt at $\mathrm{pH}$ 7.4.

\section{Halophiles and Food biotechnology}

The use of halophilic fermentation has a number of advantages in relation to the production of salt-containing food. The fermentation products give taste, aroma, and flavor, and it has been shown that the production of acetate as a fermentation product protects food from contamination with spoilage-yeasts ${ }^{33}$. Halophilic or halotolerant fermentative bacteria have been used to produce a wide variety of food products, notably fermented fish, shrimp, meat, fruits, and vegetables (pickles), Asian fish and meat sauces, rice noodles and flours, and Indonesian soy sauce ${ }^{33,36,37}$. Most of the bacteria reported to be being involved in food production are non-obligate halophiles, including species of the genera Lactobacillus, Halobacterium, Halococcus, Bacillus, Pediococcus, and Tetragenococcus ${ }^{33,36,37}$. In addition to the fermentation products, halophilic bacteria have been used to produce dietary supplements, such as polyunsaturated long-chain fatty acids, and colorants, such as $\beta$-carotene ${ }^{38 \text {, }}$ ${ }^{39,40}$ Polyunsaturated fatty acids are vital for human nutrition and have traditionally been added to food in form of fish oil, which, however, might give the food undesired taste or odor ${ }^{33}$ a problem which may be avoided by the use of halophile-derived 
fatty acids.

\section{Production of $\boldsymbol{\beta}$-carotene by Dunaliella}

The cultivation of the green algae Dunaliella salina and D. bardawil for the production of â-carotene remains the most important application of halophile biotechnology ${ }^{41}$, 42. The first pilot plant for the mass culture of Dunaliella was introduced during the mid-1960s in the Ukraine, and since then commercial Dunaliella growing operations have been set up in a number of countries, particularly for the production of the pigment $\beta$-carotene which is in high demand as an antioxidant, and a source of pro-vitamin A (retinol), as well as a food colorant. The antioxidant properties of $\beta$-carotene also make it popular health food supplement. While this compound is present in many algae and higher plants and can also be synthesized chemically. The chemical product however, differs from that produced by Dunaliella in that the synthetic form consist solely of trans $\beta$-carotene, while the algal also contains a high percentage of 9 - cis $\beta$-carotene, which is a more effective quencher of singlet oxygen and other free radicals than is the pure trans form. Not all authorities are however, convinced that the addition of $\beta$-carotene to the human diet is necessarily beneficial. Both $D$. salina and $D$. bardawil produce large amounts of $\beta$ carotene when grown under suitable conditions, the pigment being found concentrated in small globules between the thylakoids of the cell's single chloroplast. The major environmental conditions stimulating the accumulation of this pigment are high light intensities, high salinity and nutrient limitation; the slower the cells grow in the presence of high irradiation levels, the more pigment is formed. Some strains may then produce more than $10 \%$ of their dry weight as $\beta$-carotene ${ }^{43}$.

A variety of technologies are used to grow beta-carotene rich Dunaliella biomass in various countries, including Australia, USA, China and Israel. These approaches vary from cultivation in large lagoons to intensive growth systems at high cell densities under carefully controlled conditions. In extensive open pond systems, no mixing is applied, and the growth conditions are poorly controlled. Intensive cultivation of Dunaliella, on the other hand, is a high technology operation where all parameters are controlled. Using a $3000 \mathrm{~m} 2$ shallow (20 cm deep) paddlewheel driven raceway ponds an average yield of $200 \mathrm{mg}$ $\beta$-carotene per m 2 per day can be obtained ${ }^{44}$. A two stage operation is often advantageous. Firstly, a large biomass is produced by the addition of high nutrient levels. Under these conditions the cells produce only a small amount of $\beta$-carotene. In the second stage, nitrate limitation is induced to stimulate carotenogenesis ${ }^{44}$ Predatory ciliates sometimes cause losses in outdoor mass cultures of Dunaliella, and different strategies have to be used to minimize the problem. Finally, superintensive cultivation systems in closed bioreactors can be used which allow for the production of high cell densities with cells having a high $\beta$-carotene content which is enriched in the 9- Cis $\beta$-carotene isomer ${ }^{45,46}$.

\section{Glycerol production by Dunaliella}

Glycerol can also be produced by the alga Dunaliella $a^{47}$ with cells grown in near-saturated $\mathrm{NaCl}$ solutions containing as much as 6-7 M intracellular glycerol. Mass cultivation of Dunaliella for the commercial production of glycerol is effective ${ }^{48}$,but because of the low price of glycerol produced by other methods (as a byproduct of the manufacturing of animal and vegetable oils), and due to the high cost of the harvesting algal cells, no commercially feasible process has yet been developed.

\section{Environmental Applications of Halophilic Bacteria Biodegradation of heavy oils}

A halophilic bacterium, strain TM-1, was isolated from the reservoir of the Shengli oil field in East China. Strain TM-1, and shown to be able to degrade crude oils. It is a gram-positive nonmotile coccus which grow at up to $58^{\circ} \mathrm{C}$ and in an $18 \% \mathrm{NaCl}$ solution. The strain was found to be a facultative aerobe capable of growth under anaerobic conditions. Moreover, it produces butylated hydroxytoluene, 1,2benzenedicarboxylic acid-bis ester and dibutyl phthalate and can use a variety of organic substrates. Laboratory studies showed that strain TM-1 can degrade and change the properties of the oil and when grown on heavy oils can lead to a loss of aromatic hydrocarbons, resins and asphaltenes $^{49}$.

\section{Decolorization of textile azo dyes}

Among 27 strains of halophilic and halotolerant bacteria isolated from effluents of textile industries, three showed a marked ability to 
decolorize widely utilized azo dyes. Phenotypic characterization and phylogenetic analysis based on $16 \mathrm{~S}$ rDNA sequence comparisons show that these strains belong to the genus Halomonas. The three strains can decolorize azo dyes in a wide range of $\mathrm{NaCl}$ concentration (up to $20 \% \mathrm{w} / \mathrm{v}$ ), temperature $\left(25-40^{\circ} \mathrm{C}\right)$, and $\mathrm{pH}(5-11)$ after 4 days of incubation in static culture; they are also able to decolorize a mixture of dyes. These strains also readily grow in and decolorize high concentrations of dye (5000 ppm) and can tolerate concentrations of up to 10,000 ppm of the dye. Decolorization appears to be due to biodegradation by a reduction of the azo bond, followed by cleavage ${ }^{50}$.

\section{Biological waste treatment}

The potential of halophilic anaerobic fermentative bacteria for use in anaerobic treatment of saline waste waters has been reported ${ }^{5152}$. For this purpose, halophilic fermentative bacteria have many advantages over 'conventional biological treatment systems'. For example, they can operate in high salt concentrations and may tolerate heavy metals and be capable of degrading a wide range of organic compounds $8,53,54,55$. According to Oren et al. (1992) ${ }^{56}$ halophilic microorganisms play a major role in the biodegradation of pollutants in hypersaline environments. The potential of two halophilic fermentative bacteria, $H$. praevalens and O. marismortui, to biodegrade substituted aromatic compounds including nitrobenzene, o-nitrophenol, m-nitrophenol, p-nitrophenol, nitroanilines, 2,4dinitrophenol, and 2,4-dinitroaniline was confirmed $^{56}$. In addition, the biodegradation of many nitro-substituted aromatic compounds (initial concentrations $50-100 \mathrm{mg} / \mathrm{l}$ ) was completed within $24 \mathrm{~h}$. Other compounds which can be degrade by halophilic microorganisms include saturated and aromatic hydrocarbons (by archaeal members), and aromatic compounds, organophosphorus compounds, and formaldehyde by eubacterial members $^{57}$. Finally halophiles may find an important role in the degradation of PCBs ${ }^{58}$.

\section{CONCLUSION}

To date, halophilic microorganisms have found relatively few commercially viable applications. Demand for salt-tolerant enzymes in current manufacturing or related processes are currently limited, but may be extended in the future.
This review has highlighted other uses of halophilic microorganisms, including their use in the treatment of saline and hypersaline wastewaters, and in the production of exopolysaccharides, poly âHalobacterium hydroxyalkanoate bioplastics and biofuels. Many of these processes have yet to be fully exploited, but the future use of halophiles in biotechnology looks very positive.

\section{REFERENCFS}

1. DasSarma S and Arora P. Genetic analysis of the gas vesicle gene cluster in haloarchaea. FEMS Microbiolo. Lett., 1997;153: 1-10.

2. Oren, A. The bioenergetic basis for the metabolic diversity at increasing salt concentrations: implications for the functioning of salt lake ecosystem. Hydrobiologia., 2001; 466: 61-72.

3. Santos, H., Da Costa, M.S. Compatible solutes of organisms that live in hot saline environments. Environ. Microbiolo., 2002; 4: 501 -509.

4. Fraser, Claire M.; Read, Timothy D.; Nelson, Karen E., Microbial genomes. Humana Press. 2004; 383. ISBN 1588291898. Retrieved 10 December 2010.

5. Stolp Heinz. Microbial ecology: organisms, habitats, activities. Cambridge University Press. 1998; pp 5-12.

6. Cavicchioli, Ricardo. Archaea: molecular and cellular biology. 2007; p. 32.

7. Oren, A. Diversity of halophilic microorganisms: environments, phylogeny, physiology, and applications. J. of Indust. Microbiol. \& Biotechno., 2002; 28: 56-63.

8. Zeikus, J.G., Hegge, P.W., Thompson, T.E., Phelps, T.J., Langworthy, T.A., 1983. Isolation and description of Haloanaerobium praevalens gen. nov. and sp. nov., J. of Biotechno., 1983; 152: 114-124.

9. Oren, A., Paster, B.J., Woese, C.R. Haloanaerobiaceae: a new family of moderately halophilic, obligately anaerobic bacteria. Syst. Appl. Microbiol., 1984a; 5: 71-80.

10. Oren, A., Weisburg, W.G., Kessel, M., Woese, C.R. Halobacteroides halobius gen. nov., sp. nov., amoderately halophilic anaerobic bacterium from the bottom sediments of the Dead Sea. Syst. Appl. Microbiol., 1984b; 5: 58-70.

11. Oren, A. 1983. Clostridium lortetii sp. nov., a halophilic obligatory anaerobic bacterium producing endospores with attached gas vacuoles. Arch. Microbiol., 1983; 136: 42-48.

12. Oren, A., Pohla, H., Stackebrandt, E. Transfer of Clostridium lortetii to a new genus 
Sporohalobacter gen. nov. as Sporohalobacter lortetii comb. nov., and description of Sporohalobacter marismortui sp. nov. Syst. and Appl. Microbiolo., 1987; 9(3): 239-246.

13. Cayol, J.L., Ollivier, B., Patel, B.K.C., Prensier, G., Guezennec, J., Garcia, J.L. Isolation and characterization of Halothermothrix orenii gen. nov., sp.nov., a halophilic, thermophilic, fermentative, strictly aerobic bacterium. Int. $J$. Syst. Microbiol., 1994b; 44: 534-540.

14. Liaw, H.J., Mah, R.A. Isolation and characterization of Haloanaerobacter chitinovorans gen. nov., sp. nov., a halophilic, anaerobic, chitinolytic bacterium from a solar saltern. Appl. Environ. Microbiol. 1992; 58: 260266.

15. Simankova, M.V., Chernych, N.A., Osipov, G.A., Zavarzin, G.A. Halocella cellulolytica gen. nov., sp. nov., a new obligately anaerobic, halophilic, cellulolytic bacterium. Syst. Appl. Microbiol., 1993; 16: 385-389.

16. Zhilina, T.N., Zavarzin, G.A. A new extremely halophilic homoacetogen bacteria Acetohalobium arabaticum, gen. nov., sp. nov. Dokl. Akad. Nauk. SSSR., 1990; 311: 745-747.

17. Rainey, F.A., Zhilina, T.N., Boulygina, E.S., Stackebrandt, E., Tourova, T.P., Zavarzin,G.A. The taxonomic status of the fermentative halophilic anaerobic bacteria: description of Haloanaerobiales ord. nov., Halobacteroidaceae fam. nov., Orenia gen. nov. and further taxonomic rearrangements at the genus and species level. Anaerobe., 1995; 1: 185-199.

18. Grant, W.D., Kamekura, M., McGenity, T.J., Ventosa, A. Class III. Halobacteria class. nov., In: Boone DR, Castenholz RW, Garrity GM (eds) Bergey's manual of systematic bacteriology, vol. I, 2nd edn. Springer Verlag, New York, 2001; 294-301

19. Kamekura, M., Hamakawa, T., Onishi, H. Application of halophilic nuclease $H$ of Micrococcus varians subsp. halophilus to commercial production of flavoring agent 52 GMP, Appl. Environ. Microbiol., 1982; 44: 994995.

18. Ross, H.N.M., Grant, W.D., Harris, J.E. Lipids in archaebacterial taxonomy. In: Goodfellow M, Minnekin DE (eds) Chemical methods in bacterial systematics. Academic Press, London, 1985; 289-299.

20. Kamekura, M., Kates, M. Structural diversity of membrane lipids in members of Halobacteriaceae. Biosci. Biotechnol. Biochem., 1999; 63: 669-972.

21. Olsen GJ, Woese CR, Overbeck R., The winds of (evolutionary) change: breathing new life into microbiology. J Bacteriol 1994; 176: 1-6.

22. Oren A, Ventosa A, Grant WD., Proposed minimal standards for description of new taxa in the order Halobacteriales. Int J Syst Bacteriol 1997; 47: 233-236.

23. Ng, W.V., Kennedy, S.P., Mahairas, G.G., Berquist, B., Pan, M., Shukla, H.D., Lasky, S.R., Baliga, N.S., Thorsson, V., Sbrogna, J., Swartzell, S., Weir, D., Hall, J., Dahl, T.A., Welti, R., Goo, Y.A., Leithauser, B., Keller., K., Cruz, R., Danson, M.J., Hough, D.W., Maddocks, D.G., Jablonski, P.E., Krebs, M.P., Angevine, C.M., Dale, H., Isenbarger, T.A., Peck, R.F., Pohlschroder, M., Spudich, J.L., Jung, K.W., Alam, M., Freitas, T., Hou, S., Daniels, C.J., Dennis, P.P., Omer, A.D., Ebhardt, H., Lowe, T.M., Liang, P., Riley, M., Hood, L., DasSarma, S. Genome sequence of Halobacterium species NRC-1. Proc. Natl .Acad. Sci., 2000; 12176 12181.

24. Baliga, N.S., Bonneau, R., Facciotti, M.T., Pan ,M., Glusman, G., Deutsch, E.W., Shannon, P., Chiu, Y., Weng, R.S., Gan, R.R., Hung ,P., Date, S.V., Marcotte, E., Hood, L., Ng,W.V. Genome sequence of Haloarcula marismortui: a halophilic archaeon from the Dead Sea. Genome Erratum in: Genome. Res., 2004, 14:2510.

25. Falb, M., Pfeiffer, F., Palm, P., Rodewald, K., Hickmann, V., Tittor, J., Oesterhelt, D. Living with two extremes: conclusions from the genome sequence of Natronomonas pharaonis. Genome Res., 2005; 15:1336-1343.

26. Baas Becking, L.G.M. Historical notes on salt and saltmanufacture, Sci. Month., 1931; 32: 434446.

27. Davis, J.S. Importance of microorganisms in solar salt production in: Proceedings of the 4th Symposium on Salt vol. 1. A.L. Coogan, (ed.), Northern Ohio Geological Society, Cleveland, 1974, 369-372.

28. Javor, B.J. Industrial microbiology of solar salt production, J. Ind. Microbiol. Biotechnol., 2002; 28: 42-47.

29. Thongthai, C., McGenity, T.J., Suntinanalert, P., Grant, W.D. Isolation and characterization of an extremely halophilic archaeobacterium from traditionally fermented Thai fish sauce (nam pla), Lett. Appl. Microbiol., 1992; 14: 111-114.

30. Namwong, S., Tanasupawat, S., Visessanguan, W., Kudo, T., Itoh. T., Halococcus thailandensis sp. nov., from fish sauce in Thailand, Int. J. Syst. Evol. Microbiol., 2007; 57: 2199-2203.

31. Tapingkae, W., Tanasupawat,S., Itoh, T., Parkin, K.L., Benjakul,S., Visessanguan, W., Valyasevi, R., Natrinema gari sp. nov., a halophilic archaeon isolated from fish sauce in 
Thailand, Int. J. Syst. Evol. Microbiol., 2008; 58: 2378-2383.

32. Roh, S.W., Nam, Y.D., Chang, Y.D., Sung, Y., Kim, K. H., Oh, H.M., Bae, J.W. Halalkalicoccus jeotgali sp. nov., $a$ halophilic archaeon from shrimp jeotgal, a traditional Korean fermented seafood, Int. J. Syst. Evol. Microbiol., 2007; 57: 2296-2298.

33. Margesin, R., Schinner, F. Potential of halotolerant and halophilic microorganisms for biotechnology. Extremophiles., 2001; 5: 73-83.

34. Cendrin, F., Chroboczek, J., Zaccai, G., Eisenberg, H., Mevarech, M., Cloning, sequencing, and expression in Escherichia coli of the gene coding for malate ehydrogenase of the extremely halophilic archaeabacterium. Haloarcula arismortui. Biochemist., 1993; 32 (16): 4308-4313.

35. Kivisto, A., Santala, V., Karp, M. Hydrogen production from glycerol using halophilic fermentative bacteria. Bioresour. Technolo., 2010; 101: 8671-8677.

36. Roling, W.F.M., Van Verseveld, H.W. Characterization of Tetragenococcus halophila populations in Indonesian soy mash (kecap) fermentation. Appl. Environ. Microbiol., 1996; 62: 1203-1207.

37. Tanasupawat, S., Komagata, K., Lactic acid bacteria in fermented foods in Thailand. World J. Microbiol. Biotechnol., 1995; 11: 253-256.

38. Asker, D., Ohta, Y. Production of canthaxanthin by extremely halophilic bacteria. J. Biosci. Bioeng., 1999; 88: 617-621.

39. Nichols, D.S., Nichols, P.D., McMeekin, T.A., 1993. Polyunsatured fatty acids in Antarctic bacteria. Antarct. Sci. 1993; 5: 149-160.

40. Nichols, D.S., Russell, N.J., Polyunsaturated fatty acids in marine bacteria-a dogma rewritten. Microbiolo., 1999; 145: 767-779.

41. Ben-Amotz, A., Avron, M. The biotechnology of mass culturing Dunaliella for products of commercial interest. in: Algal and Cyanobacterial Biotechnology, R.C. Cresswell, T.A.V. Rees, and N. Shah, (eds.), Longman Scientific and Technical Press, Harlow, UK, 1989, pp. 91-114.

42. Raj, R., Hemaiswarya, S. Rengasamy, R. Exploitation of Dunaliella for $\beta$-carotene production, Appl. Microbiol. Biotechnol., 2007; 74: 517-523.

43. Ye, Z.W., Jiang, JG., Wu, G.H. Biosynthesis and regulation of carotenoids in Dunaliella: progress and prospects, Biotechnol. Adv. 2008; 26:352360.

41. Ben-Amotz, A. Dunaliella $\beta$-carotene. From science to ommerce in: Enigmatic
Microorganisms and Life in treme Environments, J. Seckbach, (ed.), Kluwer cademic Publishers, Dordrecht, 1999; 401-410.

44. Ben-Amotz, A. New mode of Dunaliella biotechnology: wo-phase growth for $\beta$-carotene production, J. Appl. hycol., 1995; 7: 65-68.

45. Garcia-Gonzalez, M., Moreno, J., Manzano, J.C., Lorencio, F.J., Guerrero, M.G. Production of Dunaliella alina biomass rich in 9-cis- $\beta$ carotene and lutein in a losed tubular photobioreactor, J. Biotechnol., 2005; 115: 8190.

46. Zhu, Y.H., Jiang, J.G. Continuous cultivation of unaliella salina in photobioreactor for the production $f \beta$-carotene, Eur. Food Res. Technol., 2008; 227: 53-959.

47. Lentzen, G., Schwarz, T. Extremolytes: natural compounds from extremophiles for versatile applications, Appl. Microbiol. Biotechnol., 2006; 72: 623-634.

48. Chen, B.J., Chi, C.H. Process development and evaluation for algal glycerol production. Biotechnol. Bioeng., 1981; 23: 1267-1287.

49. Ruixia Hao and Anhuai Lu. Biodegradation of heavy oils by halophilic bacterium. Progress in Natural Science., 2009; 19: 997-1001.

50. Asad, S., Amoozegar, M.A., Pourbabaee, A.A.,Sarbolouki, M.N. , Dastgheib, S.M.M. Decolorization of textile azo dyes by newly isolated halophilic and halotolerant bacteria. Bioresour. Technolo., 2006; 98: 2082-2088.

51. Kapdan, I.K., Erten, B. Anaerobic treatment of saline wastewater by Halanaerobium lacusrosei. Process Biochem. 2007; 42: 449-453.

52. Oren, A. The order Haloanaerobiales. Prokaryotes., 2006; 4: 809-822.

53. Bhupathiraju, V.K., Oren, A., Sharma, P.K., Tanner, R.S., Woese, C.R., McInerney, M.J. Haloanaerobium salsugo sp. nov., a moderately halophilic, anaerobic bacterium from a subterranean brine. Int. J. Syst. Bacteriol., 1994; 44: 565-572.

54. Cayol, J.L., Ollivier, B., Patel, B.K.C., Ageron, E., Grimont, P.A.D., Prensier, G., Garcia, J.L. Haloanaerobium lacusroseus sp. nov., an extremely halophilic fermentative bacterium from the sediments of a hypersaline lake. Int. J. Syst. Bacteriol., 1995; 45: 790-797.

55. Nieto, J.J., Fernández-Castillo, R., Márquez, M.C., Ventosa, A., Quesada, E., RuizBerraquero, F. Survey of metal tolerance in moderately halophilic eubacteria. Appl. Environ. Microbiol., 1989; 55: 2385-2390.

56. Oren, A., Gurevich, P., Azachi, M., Henis, Y. Microbial degradation of pollutants at high salt concentrations. Biodegradat., 1992; 3, 387-398. 
57. Oren, A., Gurevich, P., Henis, Y. Reduction of nitrosubstituted aromatic compounds by the halophilic anaerobic eubacteria Haloanaerobium praevalens and Sporohalobacter marismortui. Appl. Environ. Microbiol., 1991; 57: 3367-3370.
58. Gayathri, K.V., Vasudevan, N. Enrichment of Phenol Degrading Moderately Halophilic Bacterial Consortium from Saline Environment. J Bioremed Biodegrad., 2010; 1: 104. 